\title{
Molecular Cloning and Characterization of a Tobacco MAP Kinase Kinase That Interacts with SIPK
}

\author{
Yanhong Liu, Shuqun Zhang, and Daniel F. Klessig \\ Waksman Institute and The Department of Molecular Biology and Biochemistry, Rutgers, The State \\ University of New Jersey, 190 Frelinghuysen Rd., Piscataway 08854-8020, U.S.A. \\ Accepted 4 October 1999.
}

\begin{abstract}
A tobacco MAP kinase termed SIPK ( induced protein kinase) is activated in response to a variety of stress signals, including pathogen attack and wounding (S. Zhang and D. F. Klessig, Proc. Natl. Acad. Sci. USA 95:7225-7230, 1998; S. Zhang and D. F. Klessig, Proc. Natl. Acad. Sci. USA 95:7433-7438, 1998). Using the yeast two-hybrid system, we have identified a gene encoding a protein that interacts with SIPK but not the wounding induced protein kinase (WIPK), which is another tobacco MAP kinase. Sequence analysis indicated that this SIPK-interacting protein is a member of the MAP kinase kinase family; thus, it was named SIPK kinase (SIPKK). Co-immunoprecipitation experiments demonstrated that SIPKK and SIPK interact in vitro. Consistent with its putative function as a kinase, SIPKK phosphorylated myelin basic protein in vitro. Interestingly, SIPKK was induced at the mRNA level after Tobacco mosaic virus (TMV) infection or wounding, albeit with kinetics that are too slow to account for the activation of SIPK following these stimuli.
\end{abstract}

\begin{abstract}
Mitogen-activated protein (MAP) kinase cascades play important roles in signal transduction pathways, such as those leading to stress responses and cell proliferation, in mammalian and yeast systems. These cascades are composed of three functionally linked kinases: MAP kinase (MAPK); MAP kinase kinase (MAPKK); and MAP kinase kinase kinase (MAPKKK). After stimulation by extracellular stimuli, MAPKKK activates MAPKK by the phosphorylation of serine and serine/threonine residues in the SXXXS/T motif. As a dual-specificity kinase, MAPKK then activates MAPK through the phosphorylation of threonine and tyrosine residues in the TXY motif located between kinase subdomains VII and VIII. Activated MAPK then modulates cellular responses by the phosphorylation of various enzymes or transcription factors. In this way, extracellular stimuli are transduced into intracellular responses. In mammalian systems, there are at least
\end{abstract}

Corresponding author: Daniel F. Klessig; Telephone: 1-732-445-3805; Fax: 1-732-445-5735; E-mail: klessig@ mbcl.rutgers.edu

Current address of Shuqun Zhang: Department of Biochemistry, University of Missouri-Columbia, 117 Schweitzer Hall, Columbia 65211, U.S.A. three characterized MAPK cascades, and in yeast at least six MAPK cascades have been identified (Davis 1994; Herskowitz 1995; Hirt 1997).

Homologues of the components constituting MAPK cascades in animals have also been identified in plants. For example, CTR (Kieber et al. 1993) and NPK1 (Banno et al. 1993) are structurally related to MAPKKKs. In addition, MAPKK homologues, such as NPK2 from tobacco (Shibata et al. 1995), ZmMEK from maize (Hardin and Wolniak 1998), an MAPKK from tomato (Hackett et al. 1998), and several MAPKKs from Arabidopsis (Mizoguchi et al. 1997), have been cloned. At least 20 MAPK homologues have also been cloned in various plant species, including Arabidopsis (Mizoguchi et al. 1993, 1994), tobacco (Wilson et al. 1993; Zhang and Klessig 1997), alfalfa (Duerr et al. 1993; Jonak et al. 1993, 1995), pea (Stafstrom et al. 1993), oat, parsley, and petunia (Decroocq-Ferrant et al. 1995). Based on their amino acid sequences, these MAPKs have been classified into three groups (Hirt 1997).

A variety of studies have demonstrated that MAPKs are involved in several aspects of plant growth and development, including pollen development (Wilson et al. 1997), hormone action, and cell division (Bögre et al. 1999). They also are activated in response to a variety of stress stimuli, such as wounding and pathogen attack. For example, MMK4 of alfalfa is involved in cold, drought, and mechanical stresses (Bögre et al. 1996, 1997; Jonak et al. 1996). A salicylic acid (SA)-induced protein kinase termed SIPK, which was purified from tobacco suspension cells and the corresponding gene cloned (Zhang and Klessig 1997), was shown to be activated by various signals, including SA, fungal elicitors, Tobacco mosaic virus (TMV) infection, Cf-9-mediated recognition of the Cladosporium fulvum-encoded Avr 9 peptide, and wounding (Zhang and Klessig 1997; Zhang et al. 1998; Zhang and Klessig 1998a, 1998b; Romeis et al. 1999). In all cases examined, SIPK was activated exclusively at the posttranslational level by phosphorylation. The tobacco WIPK is also activated posttranslationally by a subset of these stimuli. Additionally, WIPK is induced at the mRNA level by wounding (Seo et al. 1995, 1999; Zhang and Klessig 1998a).

To identify the kinase responsible for SIPK activation, as well as other SIPK-interacting proteins, we used the yeast two-hybrid system. The entire SIPK open reading frame was fused in-frame to the carboxy terminus of the DNA-binding 
(DB) domain of GAL4 in the "bait" plasmid pAS2-1 and transformed into yeast strain PJ69-4A, which contains the reporter genes GAL1-HIS3, GAL2-ADE2, and GAL7-LAC Z (James et al. 1996). While the GAL4-SIPK fusion alone did not activate transcription of the GAL2-ADE2 reporter gene, it induced a slight increase in expression of GAL7-LAC Z (Table

Table 1. Quantitative $\beta$-galactosidase assay of SIPK and SIPKK interaction

\begin{tabular}{lcc}
\hline $\begin{array}{l}\text { GAL4 DNA binding } \\
\text { doman fusion }^{\text {(bait) }} \mathbf{a}^{\mathbf{a}}\end{array}$ & $\begin{array}{c}\text { GAL4 activation } \\
\text { domain fusion (prey) }^{\mathbf{a}}\end{array}$ & $\begin{array}{c}\beta \text {-Galactosidase } \\
\text { activity }^{\mathbf{b}}\end{array}$ \\
\hline pAS2-1-SIPK & pACT2-SPIKK & $23.0 \pm 0.3$ \\
pAS2-1-WIPK & pACT2-SIPKK & $4.9 \pm 0.5$ \\
pVA3-1 & pTD-1 & $42.7 \pm 2.2$ \\
pAS2-1 & pACT2-SIPKK & $2.2 \pm 0.4$ \\
pAS2-1-SIPK & pACT2 & $3.7 \pm 0.2$ \\
pAS2-1 & pACT2 & $1.7 \pm 0.2$ \\
\hline
\end{tabular}

${ }^{a}$ The GAL4 DNA binding domain in pAS2-1 and GAL4 activation domain in pACT2 are as described in the Clontech user's manual.

${ }^{b}$ Data shown are average \pm SE calculated from three independent assays.
1) and sufficient GAL1-HIS3 expression to allow growth in the absence of exogenous histidine $\left(\mathrm{His}^{+}\right)$. However, histidine auxotrophy could be restored by growing the cells in $20 \mathrm{mM}$ 3-aminotriazole (3-AT), a chemical inhibitor of the HIS3 product. A tobacco cDNA library, in which the cDNA inserts were cloned into a site $3^{\prime}$ of the GAL4 transcription activation (AD) domain in plasmid pACT2, was used for the "prey" library. Yeast colonies were sequentially selected for $\mathrm{His}^{+}$and adenine $\left(\mathrm{Ade}^{+}\right)$prototrophs followed by a liquid $\beta$ galactosidase assay. By screening approximately three million transformants, we identified one positive clone. Preliminary sequence analysis of this SIPK-interacting clone revealed the presence of motifs characteristic of MAPK kinases; thus, this clone was designated SIPK kinase (SIPKK).

To test whether SIPKK encoded a protein that could autoactivate reporter gene expression, it was retransformed into yeast strain PJ69-4A. Yeast containing SIPKK and the empty bait vector (pAS2-1) failed to grow on SD (synthetic dropout) media lacking either histidine $\left(\mathrm{His}^{-}\right)$or adenine $\left(\mathrm{Ade}^{-}\right.$) (Fig. 1); thus, SIPKK alone could not activate these

$\begin{array}{ll}\text { Bait } & \text { Prey } \\ \text { pVA3-1 } & \text { pTD1-1 } \\ \text { pAS2-1 } & \text { pACT2-SIPKK } \\ \text { pAS2-1-SIPK } & \text { pACT2-SIPKK } \\ \text { pAS2-1-SIPK } & \text { pACT2-SIPKK } \\ \text { pAS2-1-WIPK } & \text { pACT2-SIPKK } \\ \text { pAS2-1-SIPK } & \text { pACT2 }\end{array}$

Fig. 1. Interaction of SIPKK with SIPK in the yeast two-hybrid system. The entire SIPK and WIPK open reading frames were fused in-frame to the C terminus of the DNA-binding (DB) domain of GAL4 in pAS2-1 by initially releasing SIPK and WIPK from the pGEM-T vector (Zhang et al. 1998) with

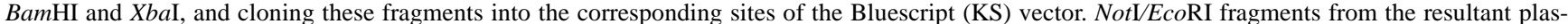
mids were then generated and cloned into corresponding sites of pLexA vectors (Clontech, Palo Alto, CA). EcoRI/SalI fragments were then generated from these plasmids (with a partial digestion for SIPK) and cloned into pAS2-1 vectors (Clontech). The prey for this two-hybrid assay consisted of a tobacco leaf cDNA library cloned into the pACT2 vector. The resultant bait- and prey-containing plasmids were then transformed into yeast strain PJ69$4 \mathrm{~A}$ by the method of Gietz and Schiestl (1995) and the yeast colonies were grown for 3 days on SD (synthetic dropout) Trp ${ }^{-}$Leu $^{-} \mathrm{His}^{-}$medium containing $20 \mathrm{mM} 3$-AT to inhibit low levels of HIS3 activity. Three million transformants were screened and $150 \mathrm{His}^{+}$clones were identified. Seven of these were found to be both $\mathrm{Ade}^{+}$and LAC Z+ ${ }^{+}$After plasmid rescue (Robzyk and Kassir 1992) and retransformation into PJ69-4A with pAS2-1-SIPK, one transformant, called SIPKK, was again able to grow on SD Trp ${ }^{-} \mathrm{Leu}^{-} \mathrm{His}^{-}$with $20 \mathrm{mM}$ 3-AT and SD $\mathrm{Trp}^{-} \mathrm{Leu}^{-} \mathrm{Ade}^{-}$media. Growth in His ${ }^{-}$and Ade plates indicates reporter gene activation. pAS2-1 and pACT2 are bait and prey vectors without inserts. pVA3-1 and pTD1-1 encode two fusion proteins that are known to interact (Clontech). 
reporter genes. In contrast, yeast co-expressing SIPKK and SIPK were prototrophic for histidine and adenine. As expected, yeast expressing SIPK plus the empty prey vector (pACT2) did not grow in the absence of histidine or adenine. Expression of the GAL7-LAC Z reporter gene was then quantified with the $\beta$-galactosidase assay (Table 1 ). Yeast containing both SIPK and SIPKK had six- and 10-fold higher levels of $\beta$ galactosidase activity than yeast expressing either SIPK or SIPKK and the corresponding empty prey or bait vectors. Moreover, the level of $\beta$-galactosidase activity exhibited by yeast expressing both SIPK and SIPKK was nearly half of that exhibited by the positive control (pVA3-1 plus pTD1-1). Taken together, these data indicate that SIPKK encodes a protein that physically interacts with SIPK in the yeast twohybrid system.

To investigate whether SIPKK specifically interacts with SIPK in the yeast two-hybrid system, WIPK, which encodes another tobacco MAP kinase (Seo et al. 1995), was cloned into pAS2-1, and then co-transformed with pACT2-SIPKK into yeast strain PJ69-4A. In contrast to yeast expressing both SIPK and SIPKK, the GAL1-HIS3 and GAL2-ADE2 reporter genes were not activated in yeast expressing both WIPK and SIPKK (Fig. 1). Similar results were obtained with the GAL7$L A C Z$ reporter gene (Table 1). These results suggest that the interaction between SIPK and SIPKK is specific.

To verify the observed interaction between SIPKK and SIPK in the yeast two-hybrid system, co-immunoprecipitation experiments were performed (Fig. 2). cDNAs encoding SIPK and SIPKK were cloned in-frame into the PET 28a(+) and PET 28c(+) expression vectors, respectively, and expressed in Escherichia coli. The resultant SIPK and SIPKK fusion proteins were then incubated together, along with an SIPKK antibody. After several washes, the co-immunoprecipitates were separated on sodium dodecyl sulfate-polyacrylamide gels and were reacted with antibodies for SIPKK or SIPK (Ab-p48N; Zhang et al. 1998). The SIPKK antibody recognized a $48-\mathrm{kDa}$ protein, which corresponds to the expected molecular mass of the SIPKK fusion protein. Moreover, since this antibody recognized the $48-\mathrm{kDa}$ protein only in assays containing SIPKK and did not cross-react with SIPK (Fig. 2B), it appears to be specific for SIPKK. Addition of the SIPKK antibody to assays containing SIPK and SIPKK resulted in the immunoprecipitation of both SIPKK (Fig. 2B) and SIPK, at the previously reported size of approximately $52 \mathrm{kDa}$ (Fig. 2A; Zhang et al. 1998). Thus, SIPK and SIPKK interact in vitro.

The 1.6-kb SIPKK cDNA clone was sequenced in its entirety and shown to contain a 1,071-bp open reading frame, a 123-bp 5' untranslated region, and a 421-bp 3' untranslated region including a poly (A) tail (GenBank accession number AF165186). Translation of this open reading frame generates a protein with a molecular mass of $39.3 \mathrm{kDa}$. A BLAST search of current data bases with the deduced SIPKK amino acid sequence revealed significant homology to several MAPKKs (Fig. 3). Of these, an MAPKK from tomato exhibited the greatest similarity to SIPKK (89\%). Comparisons of the SIPKK sequence with those of other MAPKKs revealed that SIPKK contains the 11 subdomains characteristic of protein kinases (Fig. 3; Hanks and Quinn 1990). Moreover, the TFVGT motif that is conserved in a number of MAPKKs (Nishihama et al. 1995) is present in subdomain VIII. Southern blot analysis with the SIPKK cDNA revealed that this
MAPKK most likely belongs to a multigene family in tobacco (data not shown).

To determine whether SIPKK encodes a functional kinase, an in vitro kinase assay was performed. Bacterially expressed,

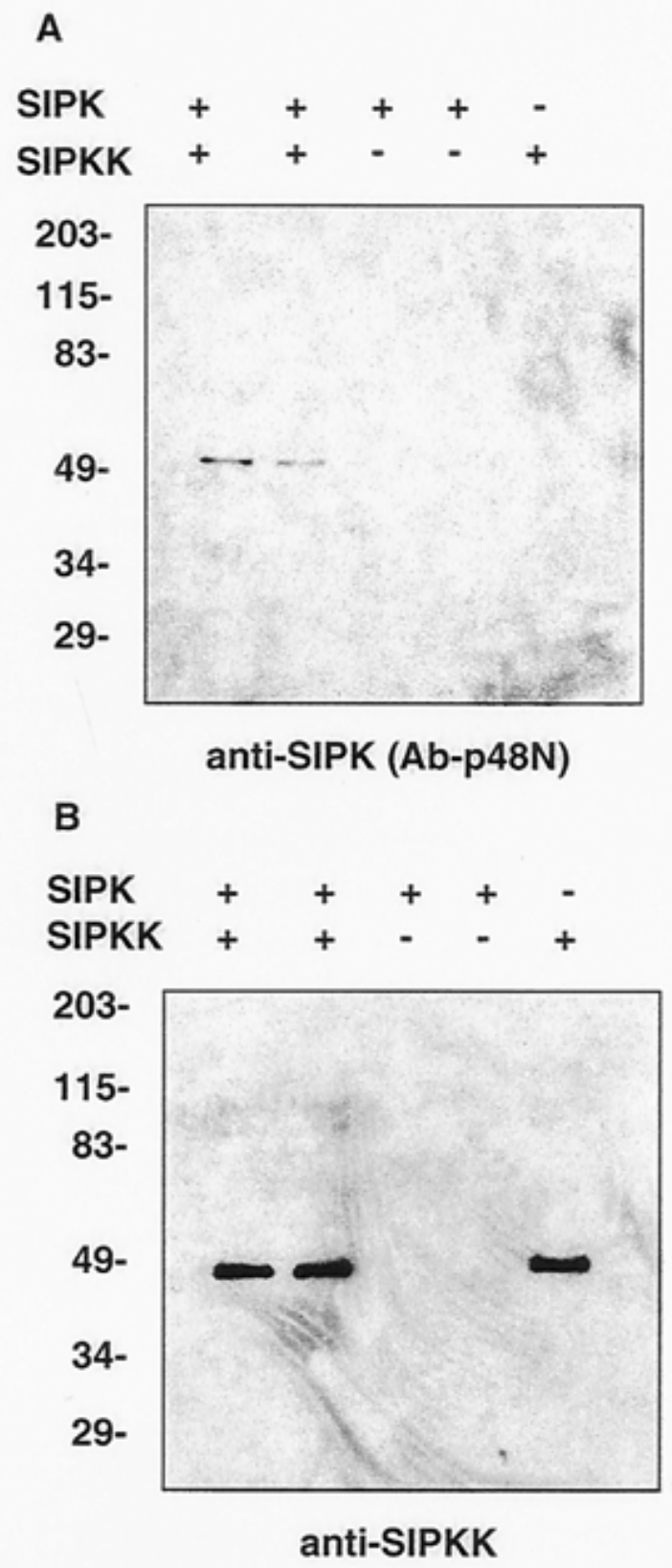

Fig. 2. SIPK co-immunoprecipitates with SIPKK. A 19-amino-acid peptide (DLGSYFTSAGPPLATLTEL), corresponding to the C terminus of the SIPKK protein, was synthesized and conjugated to keyhole limpet hemacyanin carrier. Polyclonal antisera were raised in two rabbits and purified by affinity column chromatography (Zymed Laboratory, San Francisco). SIPK antibody (Ab-p48N) was produced as described previously (Zhang et al. 1998). Co-immunoprecipitation experiments were performed essentially as described by Bower et al. (1996) except that 5 $\mu \mathrm{g}$ of SIPKK antibody was added to $100 \mu \mathrm{g}$ of total soluble protein produced in Escherichia coli expressing SIPK and/or SIPKK proteins and prepared according to the manufacturer's instructions (Novagene, Madison, WI). Immunoblot analysis was performed essentially as described by Zhang et al. (1998) except that the membranes were reacted with (A) the SIPK-specific antibody (Ab-p48N) or (B) the SIPKK antibody at a concentration of $0.5 \mu \mathrm{g} / \mathrm{ml}$. Molecular mass markers are shown in $\mathrm{kDa}$. 


\begin{abstract}
$\begin{array}{ll}\text { SIPKK }(100) & \text { MKKG SLAPNLKLSL PPPDEVNLSK FLTESGTFKD .GDLLVNRDG VRIVSQS。E VEAPSVIQPS } \\ \text { MAPKK }(89) & \text { MKKG SFAPNLKLSL PPPDEVVLSK FLTESGTFKD .GDLLVNRDG VRIVSOS。E VAAPSVIQPS }\end{array}$ Tomato MAPKK $(89)$ MAP2k $\beta(66)$ MAP kinase kinase $2(66)$ MEK1 (63) ZMMEK1 (56) MKKG GFSNNLKLAI PVAGEQSITK FLTQSGTFKD .GDLRVNKDG VRIISQL..E PEVLSPIKPA MKKG GFSNNLKLAI PVAGEQSITK FLTQSGTFKD .GDLRVNKDG VRIISQL..E PEVLSPIKPA MNRG SLCPN.PICL PPI.EOSISK FLTOSGTFKD .GDLRVNKDG IQTVSLS..E PGAPPPIEPI MKGK KPVKELKLTV P.AQETPVDK FLTASGTFKD .GELRLNQSG LRLISEENGD EDESTKLKVE MAP kinase kinase 4 (44) MRPIQSPPGV SVPVKSRPRR RPDLTLPLPQ RDVSLAVPLP LPPTSGGSGG SSGSAPSSGG SASSTNTNSS MAP kinase kinase 5 (43) MKPIQSPSGV ASPMKNRLRK RPDLSLPLPH RDVALAVPLP LPPPS.... SSSSSAPAS.S SAISTNISA. MAP kinase kinase $\alpha$ (43) MKPIQSPSGV ASPMKNRLRK RPDLSLPLPH RDVALAVPLP LPPPS..... SSSSAPAS.S SAISTNISA.
\end{abstract}

SIPKK (100) DNQLCLADFE AVKVIGKGNG GIVRLVQHKW TGQFFALKAI QMNIEESMRK HIAQELRINQ SSQVPYVVIS Tomato MAPKK (89) DNQLCLADFE SSKVIGKGNG GIVRLVQHKW TGOFFALKVI QMNIDESMRK HIAOELRINO SSOCPYVVIC MAP2k $\beta$ (66) DDQLSLSDLD MVKVIGKGSS GVVQLVQHKW TGQFFALKVI QLN DEAIRK AIAQELKINQ SSQCPNLVTS MAP kinase kinase 2 (66) DDQLSLSDLD MVKVIGKGSS GVVQLVQHKW TGQFFALKVI QLNIDEAIRK AIAQELKINQ SSQCPNLVTS MEK1 (63) DNQLSLADLE VIKVIGKGSS GNVQLVKHKL TQQFFALKVI QLNTEESTCR AISQELRINL SSQCPYLVSC ZMMEK1 (56) DVQLSMDDLE MIQVIGKGSG GVVQLVRHKW VGTLFALKGI QMNIQESVRK QIVQELKINQ ATQSPHIVMC MAP kinase kinase 4 (44) IEAKNYSDLV RGNRIGSGAG GTVYKVIHRP SSRLYALKVI YGNHEETVRR QICREIEILR DVNHPNVVKC MAP kinase kinase 5 (43)...AKSLSELE RVNRIGSGAG GTVYKVIHTP TSRPFALKVI YGNHEDTVRR QICREIEILR SVDHPNVVKC MAP kinase kinase $\alpha$ (43) ..AKSLSELE RVNRIGSGAG GTVYKVIHTP TSRPFALKVI YGNHEDTVRR QICREIEILR SVDHPNVVKC I II III IV

SIPKK (100) YQSFF..DNG AISIILEYMD GGSLADFLKK VKTIPERYLA AICKQVLKGL WYLHHEKHII HRDLKPSNLL Tomato MAPKK (89) YQSFF. .DNG AISLILEYMD GGSLADFLKK VKTIPERFLA VICKQVLKGL WYLHHEKHII HRDLKPSNLI MAP2k $\beta$ (66) YQSFY. .DNG AISLILEYMD GGSLADFLKS VKAIPDSYLS AIFRQVLQGL IYLHHDRHII HRDLKPSNLL MAP kinase kinase 2 (66) YQSFY. .DNG AISLILEYMD GGSLADFLKS VKAIPDSYLS AIFRQVLQGL IYLHHDRHII HRDLKPSNLL MEK1 (63) YQSFY..HNG LVSIILEFMD GGSLADLLKK VGKVPENMLS AICKRVLRGL CYIHHERRII HRDLKPSNLI ZMMEK1 (56) HQSFY. .HNG VIYLVLEYMD RGSLADIVKQ VKTILEPYLA VLCKQVLEGL LYLHHQRHVI HRDIKPSNLI MAP kinase kinase 4 (44) HEMF..DQNG EIQVLLEFMD KGSL.....EG AHVWKEQQLA DLSRQILSGL AYLHS.RHIV HRDIKPSNLI MAP kinase kinase 5 (43) HDMF. .DHNG EIQVLLEFMD QGSL.... EG AHIWQEQELA DLSRQILSGL AYLHR. RHIV HRDIKPSNLI. MAP kinase kinase $\alpha$ (43) HDMF..DHNG EIQVLLEFMD QGSL.... EG AHIWQEQELA DLSRQILSGL AYLHR.RHIV HRDIKPSDLI

SIPKK(100) INHIGDVKIT DFGVSAVLAS TSGLANTFVG TYNYMSPERI L.....GGAY GYRSDIWSLG LVLLECATGV Tomato MAPKK (89) INHRGDVKIT DFGVSAVLAS TSGLANTFVG TYNYMSPERI S.....GGAY DYKSDIWSLG LVLLECATGH MAP2k $\beta$ (66) INHRGEVKIT DFGVSTVMTN TAGLANTFVG TYNYMSPERI V.....GNKY GNKSDIWSLG LVVLECATGK MAP kinase kinase 2 (66) INHRGEVKIT DFGVSTVMTN TAGLANTFVG TYNYMSPERI V.....GNKY GNKSDIWSLG LVVLECATGK

MEK1 (63) INHRGEVKIT DFGVSKILTS TSSLANSFVG TYPYMSPERI S.....GSLY SNKSDIWSLG LVLLECATGK

ZMMEK1 (56) VNRKGEVKIT DFGVSAVLA SSIGQRDTFVG TYNYMAPERI S....GSTY DYKSDIWSLG LVILECAIGR MAP kinase kinase 4 (44) INSAKNVKIA DFGVSRILA QTMDPCNSSVG TIAYMSPERI NTDLNOGKYD GYAGDIWSLG VSILEFYLGR MAP kinase kinase 5 (43) INSAKNVKIA DFGVSRILA QTMDPCNSSVG TIAYMSPERI NTDLNHGRYD GYAGDVWSLG VSILEFYLGR MAP kinase kinase $\alpha(43)$ INSAKNVKIA DFGVSRILA QTMDPCNSSVG TIAYMSPERI NTDLNHGRYD GYAGDVWSLG VSILEFYLGR

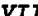
VIII $\tau \boldsymbol{X}$

SIPKK (100) FPYSPPQADE GWVINYELME TIVDQPAPSA PPDQFSPQFC SFISACVQKD QKDRLSANEL MRHPFITMYD Tomato MAPKK (89) FPYKPPEGDE GWVNVYELME TIVDQPEPCA PPDQFSPQFC SFISACVQKH QKDRLSANDL MSHPFITMYD MAP2k $\beta$ (66) FPYAPPNQEE TWTSVFELME AIVDQPPPAL PSGNFSPELS SFISTCLQKE PNSRSSAKEI MEHPFLNKYD MAP kinase kinase 2 (66) FPYAPPNQEE TWTSVFELME AIVDQPPPAL PSGNFSPELS SFISTCLQKD PNSRSSAKEL MEHPFLNKYD MEK1 (63) FPYTPPEHKK GWSSVYELVD AIVENPPPCA PSNLFSPEFC SFISQCVQKD PRDRKSAKEL LEHKFVKMFE ZMMEK1 (56) FPYIPSEG.E GWLSFYELLE AIVDQPPPSA PADQFSPEFC SFISSCIQKD PAQRMSASEL LNHPFLKKFE MAP kinase kinase 4 (44) FPFPVSRQGD. WAS...LMC AICMSQPPEA PATA.SPEFR HFISCCLQRE PGKRRSAMQL LQHPFIIRAS MAP kinase kinase 5 (43) FPFAVSRQGD .WAS. . LMC AICMSQPPEA PATA.SQEFR HEVSCCLQSD PPKRWSAQQL LQHPFILKAT MAP kinase kinase $\alpha$ (43) FPFAVSRQGD . WAS. . LMC AICMSQPPEA PATA.SQEFR HFVSCCLQSD PPKRWSAQQL LQHPFILKAT $\boldsymbol{X}$

SIPK (100) DLDIDLGSYF TSAGPPLATL TEL

Tomato MAPKK (89) DODIDLGSYF TSAGPPLATL TEL MAP2k $\beta$ (66) YSGINLASYF TDAGSPLATL GNLSGTFSV

MAP kinase kinase 2 (66) YSGINLASYF TDAGSPLATL GNLSGTFSV

MEK1 (63) DSDTNLSAYF TDAGSLIPPL AN

ZMMEK1 (56) DKDLNLGILV ENLEPPMNIP E

MAP kinase kinase 4 (44) PSQNRSPQNL HQLLPPPRPL SSSSSPTT

MAP kinase kinase 5 (43) ....GGPNL RQMLPPPRPL PSAS

MAP kinase kinase $\alpha(43)$....GGPNL RQMLPPPRPL PSAS

Fig. 3. Sequence comparison between SIPKK and other putative plant MAPKKs. Amino acid sequences of SIPKK, the tomato MAPKK (Hackett et al 1998), MAP2K $\beta$, MAP kinase kinase 2 (Ichimura et al. 1998), MEK1 (Morris et al. 1997), ZmMEK1 (Hardin and Wolniak 1998), MAP kinase kinase 4 (Ichimura et al. 1998), MAP kinase kinase 5 (Ichimura et al. 1998), and MAP kinase kinase $\alpha$ (Jouannic et al. 1996) were deduced from cDNA sequences and aligned with the PILEUP program (Wisconsin GCG package, Madison, WI). Amino acid percent identity to SIPKK is shown in parentheses. Dots represent gaps introduced to maximize alignment. The 11 conserved subdomains characteristic of protein kinase $(I-X I)$ are noted in Roman numerals. The conserved motif found in many MAPKKs is underlined in the SIPKK sequence. 
His-tagged SIPK and SIPKK were affinity purified on a nickel column and incubated in a kinase assay with $\left[\gamma^{32} \mathrm{P}\right] \mathrm{ATP}$ and myelin basic protein (MBP), which serves as a phosphorylation substrate for many MAPKs (Zhang et al. 1998). As shown in Figure 4, the SIPKK fusion protein was able to phosphorylate MBP (Fig. 4, lane 1), indicating that SIPKK encodes a kinase. SIPKK did not exhibit detectable autophosphorylation activity (Fig. 4, lane 2). By contrast, the SIPK fusion protein, which serves as the positive control, phosphory-

Fig. 4. SIPKK can phosphorylate MBP. Bacterially expressed SIPK and SIPKK proteins were purified with a nickel affinity column by the method of Zhang et al. (1998). In vitro protein kinase assays were performed essentially as described by Crews et al. (1992) except that $1 \mu \mathrm{g}$ of affinity purified recombinant protein was incubated with $20 \mathrm{mM}$ Tris$\mathrm{HCl} \mathrm{pH} \mathrm{7.5,} 10 \mathrm{mM} \mathrm{MgCl}, 2 \mathrm{mM} \mathrm{MnCl}, 1 \mathrm{mM}$ dithiothreitol, $2 \mu \mathrm{g}$ of aprotinin per $\mathrm{ml}, 10 \mu \mathrm{M}$ unlabeled ATP, and $10 \mu \mathrm{Ci}\left[\gamma^{3}{ }^{32} \mathrm{P}-\mathrm{ATP}\right]$ in the presence or absence of $1 \mu \mathrm{g}$ of MBP per $\mu \mathrm{l}$. Lane 1, SIPKK plus MBP; lane 2, SIPKK minus MBP; lane 3, SIPK plus MBP; lane 4, SIPK K-R plus MBP. Protein molecular markers are shown in $\mathrm{kDa}$.

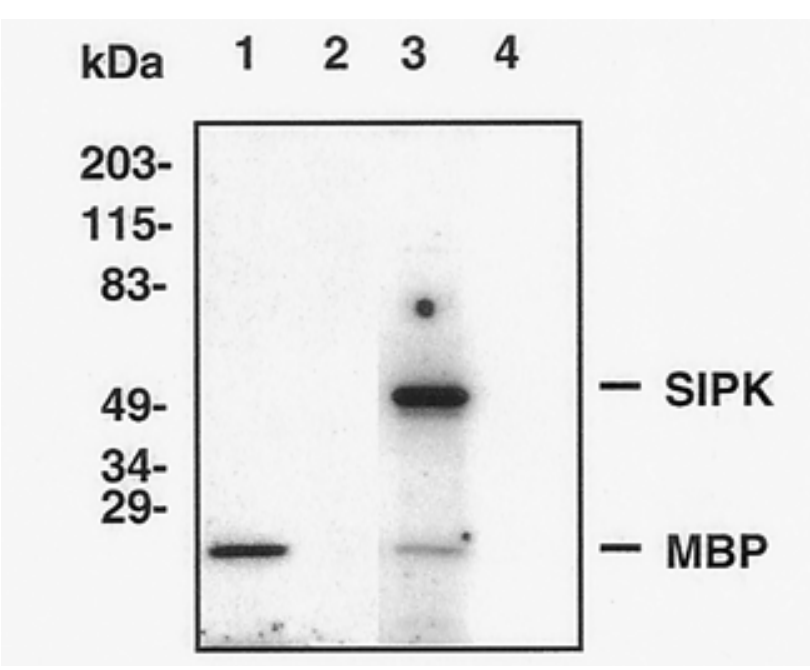

A

\section{$\begin{array}{llllllllllllllll}0 & 0.5 & 1 & 1.5 & 2 & 2.5 & 3 & 3.5 & 4 & 4.5 & 5 & 6 & 7 & 8 & 22 & \text { hps }\end{array}$}

TMV

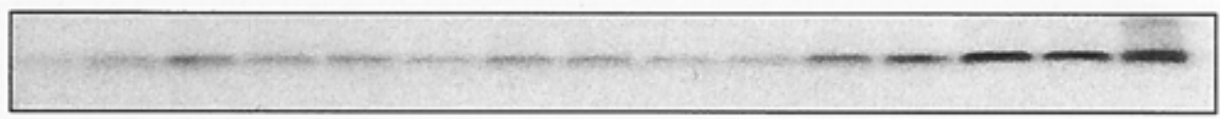

rRNA

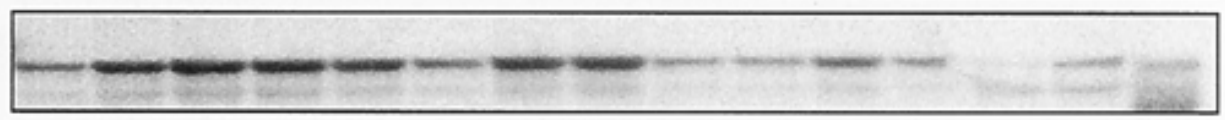

\section{$\begin{array}{llllllllllllllll}0 & 0.5 & 1 & 1.5 & 2 & 2.5 & 3 & 3.5 & 4 & 4.5 & 5 & 6 & 7 & 8 & 22 & \text { hps }\end{array}$}

MOCK

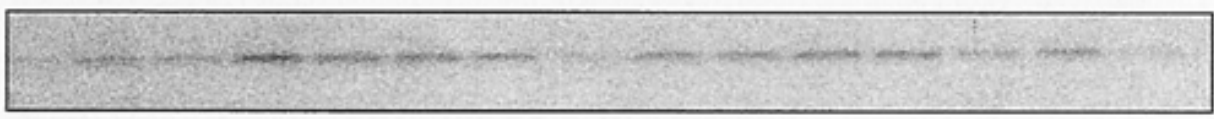

rRNA

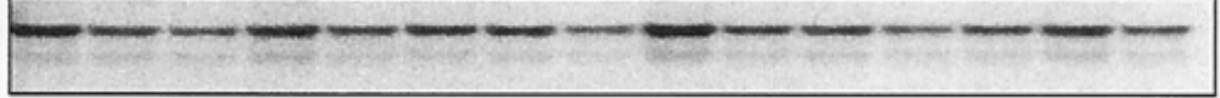

B

$$
\text { ○ - }
$$

Wounding

rRNA

Fig. 5. SIPKK is induced at mRNA level by Tobacco mosaic virus (TMV) infection and wounding. A, Tobacco plants (Nicotiana tabacum cv. Xanthi nc) grown for 6 to 8 weeks at $22^{\circ} \mathrm{C}$ were infected with TMV and maintained at $32^{\circ} \mathrm{C}$ for $48 \mathrm{~h}$, then shifted back to $22^{\circ} \mathrm{C}$ (hps, h post temperature shift), as previously described (Zhang and Klessig 1998b). Disks from infected leaves were collected at different times post temperature shift and used for isolation of total RNA according to the Trizol method (Gibco BRL, Gaithersburg, MD). Ten micrograms of total RNA per lane was separated on $1.2 \%$ agarose-formaldehyde gels, transferred to nylon membranes, and probed with the full-length SIPKK cDNA clone labeled by the random primer method (Feinberg and Vogelstein 1983). To allow normalization for differences in loading among lanes, filters were stripped and reprobed with a rDNA probe generated as described previously (Shah et al. 1997). B, Six- to 8-week-old tobacco plants grown at $22^{\circ} \mathrm{C}$ were wounded according to the method of Usami et al. (1995). At different times after wounding, total RNA was isolated and analyzed as described above. 
lated MBP as well as itself (Fig. 4, lane 3). Unfortunately, numerous attempts to demonstrate that SIPKK could phosphorylate SIPK in vitro were unsuccessful, even when the sensitivity of the assay was increased by the use of the SIPK K-R mutant. This mutant, which was generated by mutating the lysine (K) at amino acid 89 residue of SIPK to arginine (R), lacks autophosphorylation activity and, therefore, reduces the background. Our inability to show SIPK phosphorylation by SIPKK is consistent with the findings of others, who have isolated several MAPKKs and MAPKs from Arabidopsis but have encountered difficulties demonstrating MAPKKmediated phosphorylation of an MAPK in vitro (Mizoguchi et al. 1998; Ichimura et al. 1998). There is only one report demonstrating phosphorylation and activation of a plant MAPK by a plant MAPKK (Gupta et al. 1998).

Previous studies have demonstrated that SIPK and other MAPKs belonging to the SIPK subgroup are activated strictly at the posttranslational level following stress stimuli (Zhang and Klessig 1997; Zhang et al. 1998; Zhang and Klessig 1998a, 1998b). By contrast, WIPK and its subgroup members exhibit increases in both their enzymatic activity and mRNA levels in response to various stimuli (Jonak et al. 1996; Bögre et al. 1997; Seo et al. 1995; Ligterink et al. 1997; Zhang and Klessig 1998a, 1998b). For most of these MAPKs, the relatively slow accumulation of transcripts appears unlikely to account for the very rapid increase in kinase activity. However, increases in the mRNA levels of WIPK have been shown to precede both protein accumulation and kinase activation in tobacco resisting TMV infection (Zhang and Klessig 1998b). In addition, it was recently demonstrated that transcripts for MEK1, an MAPKK from Arabidopsis, accumulate in response to wounding (Morris et al. 1997). Thus, we wished to determine whether stress stimuli, such as TMV infection or wounding, increased the levels of SIPKK mRNA.

To facilitate SIPKK mRNA analysis in TMV-infected tobacco, the plants were maintained at $32^{\circ} \mathrm{C}$ for 2 days and then shifted to room temperature $\left(22^{\circ} \mathrm{C}\right)$. Because tobacco grown under elevated temperatures are unable to resist TMV infection, such a shift causes a strong, synchronous induction of many defense responses, including the accumulation of SA and pathogenesis-related (PR) proteins, the restriction of viral movement, and the development of necrotic lesions (Kassanis 1952; Gianinazzi 1970; Malamy et al. 1992). Analysis of mRNA isolated from TMV-infected plants revealed a modest increase in SIPKK transcripts that occurred around $5 \mathrm{~h}$ post temperature shift (hps; Fig. 5A). SIPKK mRNA levels then remained elevated for the remainder of the sampling period. By contrast, no increase in SIPKK transcripts was observed in mock-inoculated, temperature-shifted plants (Fig. 5A). Wounding was also observed to induce the accumulation of SIPKK transcripts. An increase in SIPKK transcripts was detected by $30 \mathrm{~min}$ after wounding and this level was maintained for the rest of the time course (Fig. 5B).

Although TMV infection and wounding have previously been shown to induce SIPK activity, the modest increase in SIPKK mRNAs following these stresses is too slow to play a role in this phenomenon. In TMV-infected tobacco, SIPK activity increased within 2 to $3 \mathrm{hps}$ (Zhang and Klessig 1998b), while rises in SIPKK transcripts were not detected until 5 hps. Similarly, although wounding induced SIPK activity within 5 min (Zhang and Klessig 1998a), SIPKK transcripts did not accumulate until after $30 \mathrm{~min}$. These results, however, do not rule out a role for SIPKK in activating SIPK. In animals, MAPKK activation occurs exclusively at the posttranslational level (Seger and Krebs 1995). Additionally, SIPK activation by a wide variety of stimuli occurs in the absence of detectable increases in mRNA levels (Zhang et al. 1998; Zhang and Klessig 1998a, 1998b). Thus, TMV infection and wounding may rapidly activate SIPKK at the posttranslational level; this activated SIPKK could then activate SIPK. Future experiments will clearly be required to help elucidate the role of SIPKK in transducing signals through the SIPK cascade.

\section{ACKNOWLEDGMENTS}

We acknowledge John Bol for providing the tobacco cDNA library and Philip James for supplying yeast strain PJ69-4A. We also thank D'Maris Dempsey for helping with the preparation of this manuscript. This work was supported by grant no. 9802200 from the U.S. Department of Agriculture.

\section{LITERATURE CITED}

Banno, H., Hirano, K., Nakamura, T., Irie, K., Nomoto, S., Matsumoto, K., and Machida, Y. 1993. NPK1, a tobacco gene that encodes a protein with a domain homologous to yeast bck1, ste11, and bry 2 protein kinases. Mol. Cell. Biol. 13:4745-4752.

Bögre, L., Calderini, O., Binarova, P., Mattauch, M., Till, S., Kiegerl, S., Jonak, C., Pollaschek, C., Barker, P., Huskisson, N. S., Hirt, H., and Heberle-Bors, E. 1999. A MAP kinase is activated late in plant mitosis and becomes localized to the plane of cell division. Plant Cell 11: 101-113.

Bögre, L., Ligterink, W., Heberle-Bors, E., and Hirt, H. 1996. Mechanosensors in plants. Nature 383:489-490.

Bögre, L., Ligterink, W., Meskiene, I., Barker, P. J., Heberle-Bors, E., Huskisson, N. S., and Hirt, H. 1997. Wounding induces the rapid and transient activation of a specific MAP kinase pathway. Plant Cell 9: 75-83.

Bower, M. S., Matias, D. D., Fernandes-Carvalho, E., Mazzurco, M. Gu, T., Rothstein, S. J., and Goring, D. R. 1996. Two members of the thioredoxin-h family interact with the kinase domain of a Brassica S locus receptor kinase. Plant Cell 8:1641-1650.

Crews, C. M., Alessandrini, A., and Erikson, R. L. 1992. The primary structure of MEK, a protein kinase that phosphorylates the ERK gene product. Science 258:478-480.

Davis, R. J. 1994. MAPKs: New JNK expands the group. Trends Biochem. Sci. 19:470-473.

Decroocq-Ferrant, V., Decroocq, S., Went, J. V., Schmidt, E., and Kreis, M. 1995. A homologue of the MAP/ERK family of protein kinase genes is expressed in vegetative and in female reproductive organs of Petunia hybrida. Plant Mol. Biol. 27:339-350.

Duerr, B., Gawlenowski, M., Ropp, T., and Jacobs, T. 1993. MsERK1: A mitogen-activated protein kinase from a flowering plant. Plant Cell 5: 87-96.

Feinberg, A. P., and Vogelstein, B. 1983. A technique for radiolabeling DNA restriction endonuclease fragments to high specific activity. Anal. Biochem. 132:6-13.

Gianinazzi, S. 1970. Hypersensibilite aux virus, temperatures et proteins solubles chez le Nicotiana tabacum cv. Xanthi-nc. C. R. Acad. Sci. Paris D. 270:2382-2386.

Gietz, R. D., and Schiestl, R. H. 1995. Transforming yeast with DNA. Methods Mol. Cell. Biol. 5:255-269.

Gupta, R., Huang, Y., Kieber, J., and Luan, S. 1998. Identification of a dual-specificity protein phosphatase that inactivates a MAP kinase from Arabidopsis. Plant J. 16:581-589.

Hackett, R. M., Oh, S. A., Morris, P. C., and Grierson, D. 1998. A tomato MAP kinase kinase gene (accession no. AJ 000728) differentially regulated during fruit development, leaf senescence, and wounding. Plant Physiol. 117:1526-1526.

Hanks, S. K., and Quinn, A.M. 1990. Protein kinase catalytic domain sequence database: Identification of conserved features of primary 
structure and classification of family members. Methods Enzymol. 200:38-62.

Hardin, S. C., and Wolniak, S. M. 1998. Molecular cloning and characterization of maize ZmMEK1, a protein kinase with a catalytic domain homologous to mitogen- and stress-activated protein kinase kinases. Planta 206:577-584.

Herskowitz, I. 1995. MAP kinase pathways in yeast: For mating and more. Cell 80:187-197.

Hirt, H. 1997. Multiple roles of MAP kinases in plant signal transduction. Trends Plant Sci. 2:11-15.

Ichimura, K., Mizoguchi, T., Irie, K., Morris, P., Giraudat, J., Matsumoto, K., and Shinozaki, K. 1998. Isolation of ATMEKK1 (a MAP kinase kinase kinase)-interacting proteins and analysis of a MAP kinase cascade in Arabidopsis. Biochem. Biophys. Res. Commun. 253:532-543.

James, P., Halladay, J., and Craig, E. A. 1996. Genomic libraries and a host strain designed for highly efficient two-hybrid selection in yeast. Genetics 144:1425-1436.

Jonak, C., Kiegerl, S., Ligterink, W., Barker, P. J., Huskisson, N. S., and Hirt, H. 1996. Stress signaling in plants: A mitogen-activated protein kinase pathway is activated by cold and drought. Proc. Natl. Acad. Sci. USA 93:11274-11279.

Jonak, C., Kiegerl, S., Lloyd, C., Chan, J., and Hirt, H. 1995. MMK2, a novel alfalfa MAP kinase, specifically complements the yeast MPK1 function. Mol. Gen. Genet. 248:686-694.

Jonak, C., Pay, A., Bögre, L., Hirt, H., and Heberle-Bors, E. 1993. The plant homolog of MAP kinase is expressed in a cell cycle-dependent and organ specific manner. Plant J. 3:611-617.

Jouannic, S., Hamal, A., Kreis, M., and Henry, Y. 1996. Molecular cloning of the asparagine synthetase gene from Asparagus officinalis L. Plant Physiol. 112:1397-1397.

Kassanis, B. 1952. Some effects of high temperature on the susceptibility of plants to infection with viruses. Ann. Appl. Biol. 39:358-369.

Kieber, J. J., Rothenberg, M., Roman, G., Feldmann, K. A., and Ecker, J. R. 1993. CTR1, a negative regulator of the ethylene response pathway in Arabidopsis, encodes a member of the raf family of protein kinases. Cell 72:427-441

Ligterink, W., Kroj, T. Nieden, U., Hirt, H., and Scheel, D. 1997. Receptor-mediated activation of a MAP kinase in pathogen defense of plants. Science 276:2054-2057.

Malamy, J., Hennig, J., and Klessig, D. F. 1992. Temperature-dependent induction of salicylic acid and its conjugates during the resistance response to tobacco mosaic virus infection. Plant Cell 4:359-366.

Mizoguchi, T. Gotoh, Y., Nishida, E., Yamaguchi-Shinozaki, K., Hayashida, N., Iwasaki, T., Kamada, H., and Shinozaki, K. 1994. Characterization of two cDNAs that encode MAP kinase homologues in Arabidopsis thaliana and analysis of the possible role of auxin in activating such kinase activities in cultured cells. Plant J. 5:111-122.

Mizoguchi, T., Ichimura, K., Irie, K., Morris, P., Giraudat, J., Matsmoto, K., and Shinozaki, K. 1998. Identification of a possible MAP kinase cascade in Arabidopsis thaliana based on pairwise yeast two-hybrid analysis and functional complementation tests of yeast mutants. FEBS Letters 437:56-60.

Mizoguchi, T., Ichimura, K., and Shinozaki, K 1997. Environmental stress response in plants: The roles of mitogen-activated protein kinases. Trends Biotechnol. 15:15-19.

Mizoguchi, T., Nayashida, N., Yamaguchi-Shinozaki, K., Kamada, H., and Shinozaki, K. 1993. ATMKs: A gene family of plant MAP kinases in Arabidopsis thaliana. FEBS Lett. 336:440-444.

Morris, P. C., Guerrier, D., Leung, J., and Giraudat, J. 1997. Cloning and characterization of MEK1, an Arabidopsis gene encoding a homologue of MAP kinase kinase. Plant Mol. Biol. 35:1057-1064.

Nishihama, R., Banno, H., Shibata, W., Hirano, K., Nakashima, M., Usami, S., and Machida, Y. 1995. Plant homologues of components of MAPK (mitogen-activated protein kinase) signal pathways in yeast and animal cells. Plant Cell Physiol. 36:749-757.

Robzyk, K., and Kassir, Y. 1992. A simple and highly efficient procedure for rescuing autonomous plasmids from yeast. Nucleic Acids Res. 20:3790.

Romeis, T., Piedras, P., Zhang, S., Klessig, D. F., Hirt, H., and Jones, J. D. G. 1999. Rapid Avr9- and Cf-9-dependent activation of MAP kinases in tobacco cell cultures and leaves: convergence of resistance gene, elicitor, wound, and salicylate responses. Plant Cell 11:273-287.

Seger, R., and Krebs, E. G. 1995. The MAPK signaling cascade. FASEB J. 9:726-735

Seo, S., Okamoto, M., Seto, H., Ishizuka, K., Sano, H., and Ohashi, Y. 1995. Tobacco MAP kinase: A possible mediator in wound signal transduction pathways. Science 270:1988-1992

Seo, S., Sano, H., and Ohashi, Y. 1999. Jasmonate-based wound signal transduction requires activation of WIPK, a tobacco mitogenactivated protein kinase. Plant Cell 11:289-298.

Shah, J., Tsui, F., and Klessig D. F. 1997. Characterization of a salicylic acid-insensitive mutant (sail) of Arabidopsis thaliana, identified in a selective screen utilizing the SA-inducible expression of the tms 2 gene. Mol. Plant-Microbe Interact. 10:69-78.

Shibata, W., Banno, H., Ito, Y., Hirano, K., Irie, K., Usami, S., Machida, C., and Machida, Y. 1995. A tobacco protein kinase, NPK2, has a domain homologous to a domain found in activators of mitogenactivated protein kinases (MAPKKs). Mol. Gen. Genet. 246:401-410.

Stafstrom, J. P., Altschuler, M., and Anderson, D. H. 1993. Molecular cloning and expression of a MAP kinase homologue from pea. Plant Mol. Biol. 22:83-90.

Usami, S., Banno, H., Ito, Y., Nishihama, R., and Machida, Y. 1995. Cutting activates a 46-kilodalton protein kinase in plants. Proc. Natl. Acad. Sci. USA 92:8660-8664.

Wilson, C., Eller, N., Gartner, A., Vicete, O., and Heberle-Bors, E. 1993. Isolation and characterization of a tobacco cDNA clone encoding a putative MAP kinase. Plant Mol. Biol. 23:543-551.

Wilson, C., Voronin, V., Touraev, A., Vicente, O., and Heberle-Bors, E. 1997. A developmentally regulated MAP kinase activated by hydration in tobacco pollen. Plant Cell 9:2093-2100.

Zhang, S., Du, H., and Klessig, D. F. 1998. Activation of the tobacco SIP kinase by both a cell wall-derived carbohydrate elicitor and purified proteinaceous elicitins from Phytophthora spp. Plant Cell 10: 435-449.

Zhang, S., and Klessig, D. F. 1997. Salicylic acid activates a 48-kDa MAP kinase in tobacco. Plant Cell 9:809-824.

Zhang, S., and Klessig, D. F. 1998a. The tobacco wounding-activated mitogen-activated protein kinase is encoded by SIPK. Proc. Natl. Acad. Sci. USA 95:7225-7230.

Zhang, S., and Klessig, D. F. 1998b. Resistance gene $N$-mediated de novo synthesis and activation of a tobacco mitogen-activated protein kinase by tobacco mosaic virus infection. Proc. Natl. Acad. Sci. USA 95:7433-7438. 